\title{
LIPOLYTIC ACTION OF CORTICOTROPIN ON RAT ADIPOSE TISSUE IN VITRO ${ }^{1,2}$
}

\author{
By J. EARLE WHITE ${ }^{3}$ AND FRANK L. ENGEL \\ (From the Departments of Medicine and Physiology, Division of Endocrinology, Duke Uni- \\ versity Medical Center, Durham, N.C.)
}

(Submitted for publication May 27, 1958; accepted July 3, 1958)

It has been reported from this laboratory that under the proper experimental conditions corticotropin is capable of modifying metabolic processes in the mouse and rat through mechanisms other than by stimulating the secretion of steroid hormones by the adrenal cortex (1-5). Similar observations have been made by Astwood (6). The metabolic responses to adrenocorticotropic hormone $(\mathrm{ACTH})$ in both intact and adrenalectomized animals bear a striking similarity to those induced by growth hormone (Table I) and some have also been elicited with the thyroid stimulating hormone $(2,3)$. Available data so far do not support the notion that these common metabolic actions are due to impurity of the hormone preparations used, with either growth hormone or some as yet unidentified "metabolic" hormone being the common contaminant.

Elsewhere the hypothesis has been proposed that the sharing of a variety of metabolic activities by pituitary hormones may simply reflect the fact that the tropic hormones serve as growth and metabolic hormones for their target glands in addition to being specific stimulators of hormone synthesis and release (3). Since the pathways for growth and general metabolism presumably are largely the same in almost all tissues it should not be surprising to find that the tropic hormones might be capable of influencing metabolism in tissues other than their target glands. The specificity of the tropic hormones might then relate either to a greater affinity of the hormone to the target gland or, alternatively, to a greater sensi-

\footnotetext{
1 Presented before the 50th Annual Meeting of the American Society for Clinical Investigation, Atlantic City, May 5, 1958.

2 Supported by grants from the American Cancer Society, the National Institute of Arthritis and Metabolic Diseases (A1324), and by Contract No. DA-49-007MD134 with the Research and Development Division, Office of the Surgeon General, Department of the Army.

3 American Diabetes Association Fellow, 1957-59.
}

tivity of the gland to the hormone. In the case of ACTH, which promotes steroidogenesis by the adrenal cortex and hence must have a potent influence on lipid metabolism in the gland, it has seemed reasonable to search for extra-adrenal influences of the hormone on pathways of lipid metabolism which might be considered analogous to those occurring in the adrenal cortex.

One of the impressive effects of ACTH is its ability to cause a loss of lipid from the adrenal cortex (7). The same hormone has been found capable of inducing ketosis, fatty liver and a loss of extractable lipid from adipose tissue depots in mice and rats $(2,4,6,8)$. The purpose of the present study was to determine whether ACTH might influence the metabolism of adipose tissue in vitro. It was found that the ACTH was highly effective in stimulating the hydrolysis of neutral fat and release of nonesterified fatty acids when incubated with rat adipose tissue in plasma and other suitable media.

\section{METHODS AND MATERIALS}

Twenty to $60 \mathrm{mg}$. portions of epididymal adipose tissue were removed from 250 to $350 \mathrm{Gm}$. Wistar rats, which had been fasted overnight and anesthetized with sodium pentobarbital injected intraperitoneally. The adipose tissue was weighed on a Roller-Smith torsion balance and then incubated in $1 \mathrm{ml}$. of pooled rat plasma at $36^{\circ} \mathrm{C}$. in a Dubnoff shaking incubator. Heparinized plasma was obtained by exsanguinating 350 to $450 \mathrm{Gm}$. male rats via the abdominal aorta and was used immediately or after refrigeration. When compared with a few pilot studies done with serum, heparinized plasma was found to yield comparable results and was therefore used for convenience. The gas phase was air or nitrogen. The $10 \mathrm{ml}$. Erlenmeyer flasks used for incubation were left unstoppered. Evaporation was retarded by enclosing the flasks in a humidifying hood.

Plasma fatty acids were determined on $0.4 \mathrm{ml}$. aliquots of plasma by the method of Dole (9) immediately and three hours after the addition of the hormone solution or an equal volume of distilled water for the control. 
TABLE I

Extra-adrenal metabolic activities common to $A C T H$ and growth hormone

Mobilize Fat from Depots (8)

Increase Liver Fat $(2,6)$

Induce Ketosis $(4,6)$

Depress R. Q. (6)

Induce Hypoglycemia $(5,6)$

Increase Glucose Tolerance (5)

Increase Adipose Tissue Glycogen (Insulinotropic) (5)

Increase Cardiac Glycogen (6)

Enhance Insulin Action on Glucose Uptake by Rat Diaphragm in Vitro (16)

Decrease Urea Formation from Infused Amino Acids in Nephrectomized Rats (3)

Tissue fatty acids were determined, after rinsing the adipose tissue samples in distilled water, by macerating them with a glass rod in the same extraction mixture used for plasma and by then following the same procedure as in the plasma method.

The following hormones were used:

Corticotropin (see Reference 4 for further description of these samples). 1. Armour Laboratories. Porcine corticotropin "A," lot No. 980-001-1, 125 U.S.P. units per mg. Protein ACTH, “Acthar-A@," lot R, J 17409, 1 unit per mg. 2. Lederle Laboratories, American Cyanamid Company. $\alpha_{1}-\alpha_{2}$ pool-lot No. S-1079-28; 80-100 U.S.P. units per mg. $\gamma$ pool-lot No. S-1079-45; 80-100 U.S.P. units per mg. $\delta-1-$ lot No. S-1079-24; 10 U.S.P. units per mg. $\beta \mathrm{P}_{\mathrm{s}}(3)-$ lot No. S-1892-34 No. 225. Peptide from pepsin digestion of ACTH; 80-100 U.S.P. units per mg. C-10-Peptide from chymotrypsin digestion of ACTH. No ACTH activity. 3. Wilson Laboratories. Oxycellulose adsorbed ACTH, lot No. 102621 ; approximately 140 U.S.P. units per mg.

These preparations were dissolved in distilled, deionized water prior to use.

Melanophore stimulating hormone (MSH). 1. $\alpha$-MSH35-B, from Dr. S. Steelman; 2. $\beta$-MSH-CCD-4, from Drs. I. Geschwind and C. H. Li.

Each preparation of MSH was dissolved in distilled, deionized water just prior to use.

Growth hormone $(S T H)$. 1. Endocrinology Study Section, National Institutes of Health. BGH-1; 2. Horner Co., Ltd., Montreal. Bovine, lot No. 17A5110X ; 3. Dr. M. Raben, human, lot No. 4.

Growth hormone was prepared immediately before use by dissolving in distilled, deionized water and adjusting to a final $\mathrm{pH}$ of 9.0 to 10.0 with $0.1 \mathrm{~N} \mathrm{NaOH}$.

Thyroid stimulating hormone (TSH). Armour Laboratories; lot IRW. Activity 1.5 to 2 U.S.P. units per mg. Estimated to contain 0.02 U.S.P. unit ACTH per mg. and negligible amounts of growth hormone. It was dissolved in distilled, deionized water just before use.

Pitressin ${ }^{\circledR}$. Parke, Davis and Company; 20 pressor units per ml., with 0.5 per cent chlorobutanol as a preservative.

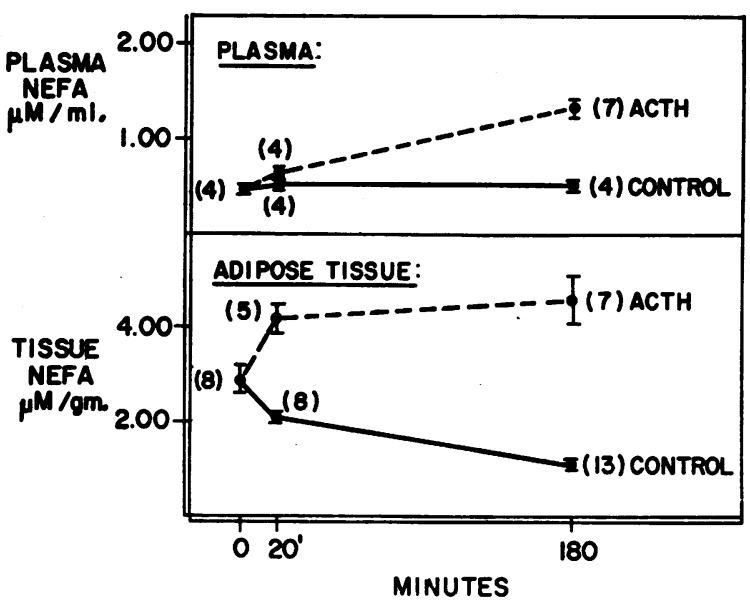

Fig. 1. Influence of OXyCel ACTH (10 $\mu$ G. PER ML.) ON the Concentration of Nonesterified Fatty Acids (NEFA) (Mean Plus or Minus S.E.) Within Adipose Tissue and Released into a Plasma Medium During Incubation in Air at $36^{\circ} \mathrm{C}$.

Pitocin. Parke, Davis and Company; 10 international units per ml., with 0.5 per cent chlorobutanol as a preservative.

\section{RESULTS}

The direct action of ACTH in promoting the release of nonesterified fatty acids from adipose tissue incubated in rat plasma is illustrated in the upper portion of Figure 1. During a three hour observation period there was no significant release of fatty acids into the medium when plasma alone, plasma and ACTH or plasma and adipose tissue were incubated. In contrast a small, but statistically significant increment in fatty acid release was already detectable in 20 minutes with a further substantial increase by 180 minutes when $10 \mu \mathrm{g}$. of oxycel ACTH was added to the plasma containing adipose tissue.

The lower panel of Figure 1 presents evidence that the release of fatty acids into the medium was not due either to a simple diffusion of intracellular fatty acids into the medium or to the release from the adipose tissue of an intracellular lipase which then hydrolyzed plasma triglycerides. Estimation of the fatty acid content of the adipose tissue itself revealed that fatty acids accumulated within the tissue promptly and in greater concentration than were released into the medium. Without hormonal stimulation the intracellular fatty acid content actually declined significantly over 


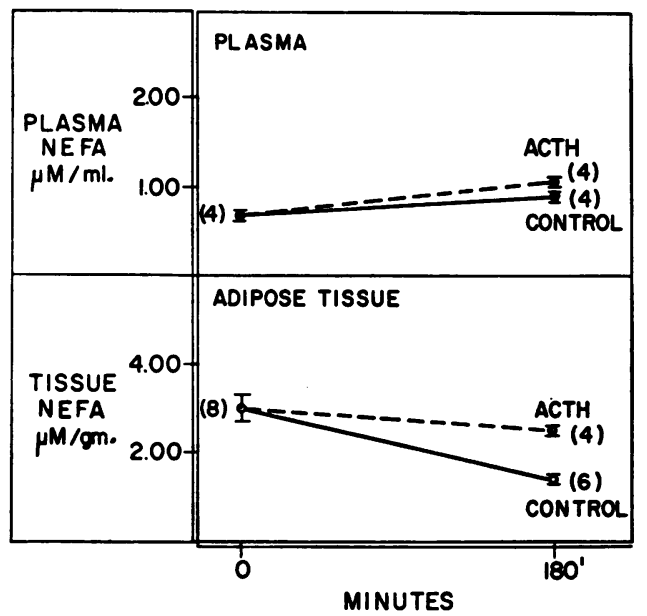

Fig. 2. Influence of OXycel ACTH (10 $\mu$ G. PER mL.) on the Concentration of Nonesterified Fatty Acids (Mean Plus or Minus S.E.) Within Adipose Tissue and Released into a Plasma Medium During Incubation in an Atmosphere of Nitrogen at $36^{\circ} \mathrm{C}$.

time. These results suggest that ACTH stimulates the hydrolysis of neutral fat within the cell with secondary release of fatty acids into the medium. Further support for this interpretation is found in the observation that when adipose tissue is incu- bated in a Krebs-Ringer phosphate medium without the addition of albumin as a fatty acid acceptor, ACTH induces an increase of fatty acids only in the tissue, with none being released into the medium (10).

Figure 2 demonstrates that the lipolytic action of ACTH on adipose tissue is largely abolished by anaerobiosis. When adipose tissue is incubated in a nitrogen atmosphere there is a small loss of fatty acids from the tissue, but this is not modified by the addition of ACTH to the degree that it is aerobically. The decline in tissue fatty acids during incubation is less under anaerobic conditions and is only slightly altered by ACTH. The lipolytic action of ACTH thus appears to depend on continuing aerobic metabolism of the tissue.

Results of studies on the lipolytic potency of various preparations of $\mathrm{ACTH}$ and of the chemically closely related hormones, $\alpha$ and $\beta$ melanophore stimulating hormones ( $\alpha$ and $\beta$ MSH), are found in Table II. An old sample of Armour $\mathrm{ACTH}$, presumably protein in nature, and assaying 1 unit per mg., was inactive at a level of $5 \mu \mathrm{g}$. per ml. of plasma but active at $10 \mu \mathrm{g}$. and greater. This same preparation was not active in causing

TABLE II

Influence of corticotropin and melanophore stimulating hormones (MSH) on production of nonesterified fatty acids (NEFA) from adipose tissue in vitro

\begin{tabular}{|c|c|c|c|c|}
\hline Hormone & $\begin{array}{c}\text { No. of } \\
\text { determinations }\end{array}$ & Dose & $\begin{array}{l}\mu \mathrm{M} \text { NEFA produced } / 100 \mathrm{mg} \text {. } \\
\text { adipose tissue } / 3 \mathrm{hrs} . \\
( \pm \mathrm{S} . \mathrm{E} .)\end{array}$ & p \\
\hline & & $\mu g . / m l$. & & \\
\hline Control & 28 & & $0.19 \pm 0.06$ ( \pm 0.29 S. D.) & \\
\hline "Protein" ACTH & 5 & 5 & $-0.08 \pm 0.04$ & $*$ \\
\hline "Protein" ACTH & 7 & 10 & $0.70 \pm 0.17$ & $<0.01$ \\
\hline "Protein" ACTH & 4 & 50 & $1.55 \pm 0.04$ & $<0.01$ \\
\hline "Protein" ACTH & 4 & 100 & $1.64 \pm 0.28$ & $<0.01$ \\
\hline Oxycel ACTH & 8 & 1 & $1.08 \pm 0.15$ & $<0.01$ \\
\hline Corticotropin "A" & 2 & 8 & 2.39 & + \\
\hline Corticotropin "A" & 1 & 16 & 2.30 & $t$ \\
\hline$\alpha_{1}-\alpha_{2}$ ACTH & 6 & 10 & $1.65 \pm 0.09$ & $<0.01$ \\
\hline$\alpha_{1}-\alpha_{2} \mathrm{ACTH}$ & 3 & 20 & $1.73 \pm 0.25$ & $<0.01$ \\
\hline$\gamma$ pool ACTH & 2 & 6 & 1.38 & $t$ \\
\hline$\gamma$ pool ACTH & 1 & 12 & 2.42 & $t$ \\
\hline$\delta-1$ ACTH & 1 & 10 & 1.74 & $t$ \\
\hline$\delta-1$ ACTH & 1 & 20 & 1.87 & $t$ \\
\hline$\beta P_{\mathrm{s}}$ (3) ACTH & $\overline{1}$ & 10 & 2.27 & $t$ \\
\hline$\beta \mathrm{P}_{\mathrm{s}}$ (3) ACTH & 1 & 20 & 1.56 & $t$ \\
\hline $\mathrm{C}-10$ & 3 & 10 & $0.16 \pm 0.08$ & $*$ \\
\hline$C-10$ & 1 & 20 & 0.29 & * \\
\hline$\alpha-\mathbf{M S H}$ & 2 & 100 & 0.35 & $*$ \\
\hline$\alpha-\mathbf{M S H}$ & 2 & 200 & 0.53 & * \\
\hline$\beta-\mathrm{MSH}$ & 2 & 200 & 0.27 & * \\
\hline$\beta-\mathrm{MSH}$ & 2 & 400 & 0.21 & * \\
\hline
\end{tabular}

* Not significantly different from control.

$\dagger$ Exceeds control by more than two standard deviations. 
TABLE III

Inactivation of $\mathrm{ACTH}$ with $\mathrm{NaOH}$ and $\mathrm{H}_{8} \mathrm{O}_{3}$, and the reactivation of $\mathrm{H}_{8} \mathrm{O}-\mathrm{ACTH}$ with cysteine

\begin{tabular}{|c|c|c|c|c|}
\hline Treatment & $\begin{array}{l}\text { No. of } \\
\text { determi- } \\
\text { nations }\end{array}$ & Dose & $\begin{array}{c}\mu \mathrm{M} \text { NEFA produced } / 100 \mathrm{mg} . \\
\text { adipose tissue/3 hrs. } \\
( \pm \mathrm{S} . \mathrm{E} .)\end{array}$ & p \\
\hline 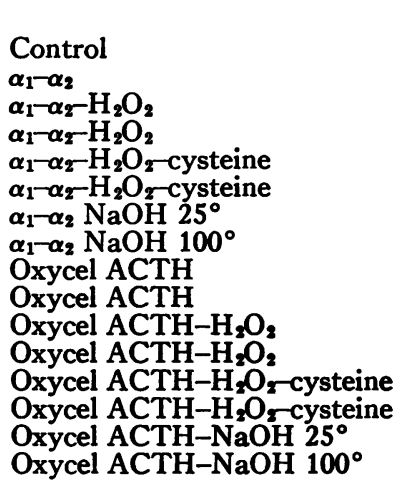 & $\begin{array}{r}28 \\
6 \\
1 \\
1 \\
1 \\
1 \\
1 \\
2 \\
8 \\
7 \\
4 \\
4 \\
4 \\
4 \\
4 \\
4\end{array}$ & $\begin{array}{r}\text { Mg./ml. } \\
10 \\
10 \\
20 \\
10 \\
20 \\
10 \\
8 \\
1 \\
10 \\
2 \\
20 \\
2 \\
20 \\
10 \\
10\end{array}$ & $\begin{array}{l}0.19 \pm 0.06( \pm 0.29 \text { S. D. }) \\
1.65 \pm 0.19 \\
0.23 \\
0.21 \\
1.24 \\
1.07 \\
1.58 \\
0.30 \\
1.12 \pm 0.21 \\
2.11 \pm 0.31 \\
0.23 \pm 0.06 \\
0.53 \pm 0.19 \\
2.28 \pm 0.67 \\
3.44 \pm 0.02 \\
1.95 \pm 0.26 \\
0.05 \pm 0.08\end{array}$ & $\begin{array}{c}<0.01 \\
* \\
* \\
\dagger \\
\dagger \\
t^{*} \\
<0.01 \\
<0.01 \\
* \\
* \\
<0.01 \\
<0.01 \\
<0.01 \\
*\end{array}$ \\
\hline
\end{tabular}

* Not significantly different from control.

† Exceeds control by more than two standard deviations.

ketosis in the rat (4). One $\mu$ g. of oxycellulose ACTH actively stimulated fatty acid release. Corticotropin A, the pure, chemically characterized peptide ACTH consisting of 39 amino acids, was active at two doses, but limitation of supply precluded further testing. Both $\alpha_{1}-\alpha_{2}$ ACTH and the $\gamma$-pool, mixtures of ACTH peptides obtained in the purification of oxycellulose ACTH by countercurrent distribution by Shepherd and associates (11) and having high ACTH potency, had lipolytic activity. Both of these samples have potent ketogenic and adipokinetic activities in rats and mice $(4,12) . \delta-1$, a fraction of lower ACTH potency, was lipolytic, although it had previously been found not to be ketogenic. On the other hand, it is of interest that Steelman (12) has found it to be a potent adipokinetic agent in the mouse. $\beta \mathrm{P}_{\mathrm{s}}(3)$, a peptide derived by graded pepsin digestion of $\beta$-corticotropin such that 10 amino acids were removed from the tail of molecule, leaving a 29 amino acid peptide with persisting ACTH activity, had lipolytic activity in vitro and adipokinetic in vivo (12), although ketogenic activity was much decreased (4). Finally, Lederle fraction C-10, a product of chymotrypsin digestion of $\beta$-corticotropin and comprising the peptide chain from amino acid 16 to 36 (3), was quite inert, as it has been in all parameters tested to date. $\alpha$ and $\beta$ MSH, 13 and 18 amino acid peptides with striking structural similarities to the corresponding $\mathrm{N}$-terminal amino acid sequence of $\beta$ ACTH (13), were inactive in high doses in the lipolysis test. $\alpha \mathrm{MSH}$ is free of adipokinetic activity (12), and $\beta \mathrm{MSH}$ does not stimulate ketosis (4).

Previous studies have shown that various procedures which may inactivate and reactivate ACTH as judged by adrenal ascorbic depleting activity usually have comparable effects on the extra-adrenal activities $(4,5)$. (The effects of pepsin and chymotrypsin digestion on ACTH activity have already been described.) ACTH may be inactivated by oxidation with $\mathrm{H}_{2} \mathrm{O}_{2}$ and reactivated by incubation with a suitable reducing agent, such as cysteine (14). Table III presents data showing that the in vitro lipolytic activity of $\alpha_{1}-\alpha_{2}$ and oxycel ACTH on adipose tissue follows a similar pattern with $\mathrm{H}_{2} \mathrm{O}_{2}$ and cysteine treated ACTH. Activity was lost on oxidation with $\mathrm{H}_{2} \mathrm{O}_{2}$ and restored by reduction with cysteine. ACTH resists mild alkali treatment $(0.1 \mathrm{~N} \mathrm{NaOH}$ at $25^{\circ}$ C. for 24 hours) but is destroyed by boiling in $0.1 \mathrm{~N} \mathrm{NaOH}$ for 20 minutes (4). The lipolytic activity of $\alpha_{1}-\alpha_{2}$ and oxycel ACTH behaved in a corresponding fashion. These results lend strength to the view that the lipolytic response is a specific activity of ACTH and not due 
to contamination with some other pituitary hormone.

Further support for this interpretation is found in Table IV which compares the lipolytic activity of ACTH with other pituitary hormones. Whereas $1 \mu \mathrm{g}$. of oxycel ACTH stimulated fatty acid release, growth hormone (STH) and thyroid stimulating hormone (TSH) showed no or at best limited activity. One sample of bovine and one of human STH were inactive even at a level of $1 \mathrm{mg}$. per $\mathrm{ml}$. while another bovine STH sample was active at levels of 100 to $200 \mu \mathrm{g}$. per ml. The TSH preparation induced lipolysis at 500 and $1,000 \mu \mathrm{g}$. but not at $100 \mu \mathrm{g}$. Preliminary studies indicate that in contrast to $\mathrm{ACTH}, \mathrm{STH}$ activity is not eliminated by oxidation with $\mathrm{H}_{2} \mathrm{O}_{2}$. The known contamination of these hormones with ACTH does not account for their lipolytic activity. It is not clear why increasing levels of the active STH and TSH preparations did not bring about as great fatty acid release as did the maximally effective dose of ACTH. The different behavior of ACTH compared to STH and TSH in this system essentially eliminates further need to consider the possibility that the ACTH effects are due to contamination with either one or both of the above hormones. Both Pitressin ${ }^{\circledR}$ and Pito$\operatorname{cin}{ }^{\circledR}$ were likewise inactive, an important consideration in view of Ingle and Li's finding that vasopressin was responsible for the presumed extraadrenal effect of ACTH in the muscle work test (15).

\section{DISCUSSION}

The direct action of ACTH on fatty acid production by adipose tissue represents the most clear demonstration yet that this hormone is capable of influencing metabolic processses under circumstances in which the mediation of adrenal cortical secretion is completely eliminated. The only other extra-adrenal in vitro effect of $\mathrm{ACTH}$ with which we are familiar is that reported by Randle and Young (16). These investigators found that corticotropin enhanced the action of insulin on glucose uptake when added to rat diaphragm in vitro. The significance of their results is

TABLE IV

Influence of pituitary hormones on production of NEFA* from adipose tissue in vitro

\begin{tabular}{|c|c|c|c|c|c|}
\hline Hormone & $\begin{array}{l}\text { No. of } \\
\text { determi- } \\
\text { nations }\end{array}$ & & ose & $\begin{array}{c}\mu \mathrm{M} \text { NEFA produced } / 100 \mathrm{mg} . \\
\text { adipose tissue } / 3 \mathrm{hrs} . \\
( \pm \mathrm{S} . \mathrm{E.})\end{array}$ & p \\
\hline $\begin{array}{l}\text { Control } \\
\text { Oxycel ACTH } \\
\text { Oxycel ACTH } \\
\text { Oxycel ACTH } \\
\text { Oxycel ACTH } \\
\text { Oxycel ACTH } \\
\text { Oxycel ACTH } \\
\text { Oxycel ACTH } \\
\text { Human STH } \\
\text { Human STH } \\
\text { STH-R50109 } \\
\text { STH-R50109 } \\
\text { STH-17A5110x } \\
\text { STH-17A5110x } \\
\text { STH-17A5110x } \\
\text { STH-17A5110x } \\
\text { STH-17A5110x } \\
\text { TSH-IRW } \\
\text { TSH-IRW } \\
\text { TSH-IRW } \\
\text { Pitressin @ } \\
\text { Pitressin @ } \\
\text { Pitressin @ } \\
\text { Pitocin @ } \\
\text { Pitocin @ } \\
\text { Pitocin @ }\end{array}$ & $\begin{array}{r}28 \\
4 \\
8 \\
4 \\
10 \\
7 \\
2 \\
2 \\
2 \\
2 \\
4 \\
5 \\
3 \\
5 \\
6 \\
10 \\
6 \\
4 \\
4 \\
4 \\
3 \\
3 \\
3 \\
3 \\
3 \\
3\end{array}$ & $\begin{array}{r}0.5 \\
1 \\
2 \\
5 \\
10 \\
100 \\
1,000 \\
500 \\
1,000 \\
500 \\
1,000 \\
10 \\
100 \\
200 \\
500 \\
1,000 \\
100 \\
500 \\
1,000 \\
0.02 \\
0.20 \\
2.00 \\
0.01 \\
0.10 \\
1.00\end{array}$ & $\begin{array}{l}\mu \mathrm{gg} / / \mathrm{ml} . \\
\mu \mathrm{g} . / \mathrm{ml} . \\
\mu \mathrm{g} . / \mathrm{ml} . \\
\mu \mathrm{g} . / \mathrm{ml} . \\
\mu \mathrm{g} . / \mathrm{ml} . \\
\mu \mathrm{g} . / \mathrm{ml} . \\
\mu \mathrm{g} . / \mathrm{ml} . \\
\mu \mathrm{g} . / \mathrm{ml} . \\
\mu \mathrm{g} . / \mathrm{ml} . \\
\mu \mathrm{g} . / \mathrm{ml} . \\
\mu \mathrm{g} . / \mathrm{ml} . \\
\mu \mathrm{g} . / \mathrm{ml} . \\
\mu \mathrm{g} . / \mathrm{ml} . \\
\mu \mathrm{g} . / \mathrm{ml} . \\
\mu \mathrm{g} . / \mathrm{ml} . \\
\mu \mathrm{g} . / \mathrm{ml} . \\
\mu \mathrm{g} . / \mathrm{ml} . \\
\mu \mathrm{g} . / \mathrm{ml} . \\
\mu \mathrm{g} . / \mathrm{ml} . \\
\mathrm{U} / \mathrm{ml} . \\
\mathrm{U} / \mathrm{ml} . \\
\mathrm{U} / \mathrm{ml} . \\
\mathrm{U} / \mathrm{ml} . \\
\mathrm{U} / \mathrm{ml} . \\
\mathrm{U} / \mathrm{ml} .\end{array}$ & $\begin{array}{l}0.19 \pm 0.06( \pm 0.29 \mathrm{~S} . \mathrm{D} .) \\
0.37 \pm 0.11 \\
1.08 \pm 0.15 \\
1.59 \pm 0.11 \\
2.37 \pm 0.28 \\
2.11 \pm 0.31 \\
2.16 \\
2.16 \\
0.00 \\
0.17 \\
0.18 \pm 0.08 \\
0.26 \pm 0.07 \\
-0.05 \pm 0.13 \\
0.53 \pm 0.14 \\
0.88 \pm 0.12 \\
0.87 \pm 0.10 \\
0.85 \pm 0.15 \\
0.34 \pm 0.06 \\
0.86 \pm 0.27 \\
1.47 \pm 0.35 \\
0.18 \pm 0.11 \\
0.34 \pm 0.12 \\
0.44 \pm 0.22 \\
0.19 \pm 0.12 \\
0.25 \pm 0.06 \\
0.37 \pm 0.20\end{array}$ & $\begin{array}{r}\quad t \\
<0.01 \\
<0.01 \\
<0.01 \\
<0.01 \\
\\
\\
\dagger \\
\dagger \\
+ \\
<0.05 \\
<0.01 \\
<0.01 \\
<0.01 \\
\dagger \\
<0.01 \\
<0.01 \\
\dagger \\
\dagger \\
\dagger \\
\dagger \\
\dagger\end{array}$ \\
\hline
\end{tabular}

* Abbreviations used are as follows: NEFA, nonesterified fatty acid; ACTH, adrenocorticotropic hormone; STH, growth hormone; TSH, thyroid stimulating hormone.

$\uparrow$ Not significantly different from control. 
clouded, however, by the fact that they found peroxide and periodate "inactivated" corticotropin to be still active in this test, whereas so far we have found that all other extra-adrenal activities of ACTH have disappeared following peroxide treatment of the hormone.

On the basis of the data thus far available, it would appear that the action of the hormone is on the hydrolysis of neutral fat within the cell. This interpretation, however, cannot be accepted with finality until analysis is made of the tissue and medium for the glycerol moiety or until the specific fatty acids released are identified and estimated. Both of these procedures are planned for the near future. Gordon (17) has criticized Dole's method of analysis of nonesterified fatty acids on the grounds of inadequate specificity, with lactic acid singled out as an important interfering substance. We have tested our system for lactic acid by the Barker-Summerson method and found no change in response to ACTH stimulation (18).

The influence of ACTH on adipose tissue has a parallel in its action on the adrenal cortex. A loss of cholesterol esters and triglyceride fat from the adrenal cortex has long been known as an early and characteristic consequence of ACTH action (7). Surprisingly little specific information is available, however, about the fate of the lipid other than cholesterol in the adrenal. It is pertinent to the present study that lipase activity of the adrenal cortex has been reported to increase during ACTH stimulation (19). It would seem reasonable to suggest that the fatty acids from cholesterol esters and neutral fat in the adrenal cortex might serve as a source of fatty acyl-CoA and acetyl-CoA from which the steroids may be synthesized and that ACTH may serve to initiate the hydrolysis of fatty acid esters. Further support for the analogy between ACTH action on the adrenal cortex and adipose tissue is found in the fact that when the lipolytic effect on adipose tissues is studied in artificial media instead of plasma, the requirements for maximal activity appear to be very similar to those reported necessary for stimulation of adrenal slices by ACTH in vitro $(10,20)$. These same conditions are not required for the in vitro lipolytic action of epinephrine and norepinephrine (10, 21,22 ).

It was surprising to find that growth hormone and TSH, which are active in inducing fatty liver and ketosis in the intact animal, were relatively impotent compared to ACTH in stimulating fatty acid release from adipose tissue in vitro. This is particularly noteworthy since Raben and Hollenberg (23) have recently reported that 0.5 to 1.0 mg. of growth hormone will bring about a sustained increase in plasma fatty acids in the diabetic dog. Approximately the same quantity of growth hormone was found by Winegrad, Shaw and Renold to be necessary to demonstrate an action on glucose uptake and lipogenesis in rat adipose tissue in vitro (24). The possibility exists, as previously suggested by Krahl (25), that growth hormone may be converted to a different compound in the body before it exerts some of its effects. In any case, caution is necessary in extrapolating dose requirements from in vitro to in vivo conditions.

While the minimal dose of ACTH necessary for the lipolytic effect is many-fold less than that of growth hormone and TSH, it should be emphasized that this dose is still tremendously greater than that required to stimulate the adrenal cortex in vitro or in vivo. This is what one would anticipate if one assigns to ACTH a specific role of stimulating the adrenal cortex. The extraadrenal tissues should be expected to be much less sensitive to ACTH. Neither the present nor previous studies answer the question as to whether endogenously secreted ACTH influences extraadrenal metabolism to a significant degree, but this possibility deserves serious consideration.

The in vitro lipolytic action of $\mathrm{ACTH}$ is not unique for this hormone, epinephrine and norepinephrine having also been shown to be highly active $(21,22)$. Other hormones which have been tested and found inactive in this laboratory are prolactin (500 $\mu \mathrm{g}$. per ml.), triiodothyronine ( $50 \mu \mathrm{g}$. per $\mathrm{ml}$.), glucagon (100 $\mu \mathrm{g}$. per $\mathrm{ml}$.), serotonin $(20 \mu \mathrm{g}$. per ml.) and hydrocortisone hemisuccinate (133 $\mu \mathrm{g}$. per $\mathrm{ml}$.). The figures in parentheses are the largest doses tested.

\section{SUM MARY}

1. Incubation of corticotropin with rat adipose tissue in a rat plasma medium resulted in an increase in the concentration of nonesterified fatty acids in both the tissue and the incubating medium. This was interpreted as indicating an increased 
rate of lipolysis of neutral fat within the cell. The effect was inhibited during anaerobiosis.

2. Corticotropin $A$ and various fractions in the purification of $\beta$-corticotropin as well as a product of pepsin digestion of $\beta$-corticotropin with high adrenocorticotropic hormone (ACTH) activity all had potent lipolytic activity. When ACTH activity was destroyed by digestion with chymotrypsin, by boiling in $\mathrm{NaOH}$ or oxidation by hydrogen peroxide, lipolytic activity was also lost. In the latter case both ACTH and lipolytic activity could be restored by reduction with cysteine. These data are interpreted as indicating that the lipolytic activity is an intrinsic property of corticotropin.

3. Compared to ACTH, growth hormone and thyroid stimulating hormone had low lipolytic activity. One sample of bovine and one of human growth hormone were inactive at $1.0 \mathrm{mg}$. per $\mathrm{ml}$. Another bovine growth hormone was active at 100 to $200 \mu \mathrm{g}$. per $\mathrm{ml}$. and one sample of thyroid stimulating hormone was active at $500 \mu \mathrm{g}$. per $\mathrm{ml}$. Prolactin, Pitressin ${ }^{\circledR}$, Pitocin ${ }^{\circledR}$, triiodothyronine, hydrocortisone and serotonin were inactive.

4. These results are discussed in relation to the other known actions of ACTH on the adrenal cortex and extra-adrenal tissues.

\section{ACKNOWLEDGMENTS}

We are indebted to Dr. David Klein, the Wilson Laboratories, Chicago, to Dr. Paul Bell, Lederle Laboratories Division, American Cyanamid Company, Pear1 River, N. Y., and to Dr. W. F. White, Armour Laboratories, Chicago, for the corticotropin preparations used in this study, and to Dr. S. Steelman, Baylor University, Houston, Texas, for $\alpha \mathrm{MSH}$, to Drs. C. H. Li and I. Geschwind, the University of California, Berkeley, for $\beta \mathrm{MSH}$, the Endocrinology Study Section of the National Institutes of Health for bovine growth hormone and ovine prolactin, Dr. L. Mitchell of the Horner Company, Ltd., Montreal, for bovine growth hormone, Dr. M. Raben, New England Center Hospital, Boston, for human growth hormone, Dr. O. Behrens, the Eli Lilly Company, Indianapolis, for glucagon, Dr. A. Heming of Smith, Kline and French, Philadelphia, for triiodothyronine, and to Dr. N. O'Donovan, the Upjohn Company, Kalamazoo, Mich., for hydrocortisone hemisuccinate.

\section{REFERENCES}

1. Engel, F. L., and Engel, M. G. The influence of corticotropin on ketonemia and glycemia in normal and adrenalectomized rats. Endocrinology 1954, 55,845 .
2. Engel, F. L., Engel, M. G., and McPherson, H. T. Ketogenic and adipokinetic activities of pituitary hormones. Endocrinology 1957, 61, 713.

3. Engel, F. L. Some unexplained metabolic actions of pituitary hormones with a unifying hypothesis concerning their significance. Yale J. Biol. Med. 1957, 30, 201.

4. Engel, F. L., and Engel, M. G. The ketogenic activity of corticotropin, a presumed extra-adrenal action. Endocrinology 1958, 62, 150.

5. Engel, F. L., Fredericks, J., Lopez, E., and Albertson, T. Some extra-adrenal actions of corticotropin on carbohydrate metabolism in the rat. Endocrinology 1958 (In press).

6. Astwood, E. B. Growth hormone and corticotropin in The Hormones, G. Pincus and K. V. Thimann, Eds. New York, Academic Press Inc., 1955, vol. 3, p. 235.

7. Tepperman, J., Engel, F. L., and Long, C. N. H. A review of adrenal cortical hypertrophy. Endocrinology 1943, 32, 373.

8. White, J. E., and Engel, F. L. A direct effect of purified ACTH on depot fat in the mouse. Amer. J. Med. 1958, 25, 136.

9. Dole, V. P. A relation between non-esterified fatty acids in plasma and the metabolism of glucose. $\mathrm{J}$. clin. Invest. 1956, 35, 150.

10. White, J. E., Lopez, E., and Engel, F. L. To be published.

11. Shepherd, R. G., Howard, K. S., Bell, P. H., Cacciola, A. R., Child, R. G., Davies, M. C., English, J. P., Finn, B. M., Meisenhelder, J. H., Moyer, A. W., and Van der Scheer, J. Studies with corticotropin. I. Isolation, purification and properties of $\beta$-corticotropin. J. Amer. chem. Soc. 1956, 78, 5051.

12. Steelman, S. Personal communication.

13. Harris, J. I., and Lerner, A. B. Amino-acid sequence of the $\alpha$-melanocyte-stimulating hormone. $\mathrm{Na}$ ture (Lond.) 1957, 179, 1346.

14. Dedman, M. L., Farmer, T. H., and Morris, C. J. O. R. Studies on pituitary adrenocorticotropin. 2. Oxidation-reduction properties of the hormone. Biochem. J. 1957, 66, 166.

15. Ingle, D., and $\mathrm{Li}, \mathrm{C}$. H. Effect of pituitary extracts upon the work performance of adrenalectomizedhypophysectomized rats: Identification of vasopressin as a principle affecting work. Endocrinology 1955, 57, 383.

16. Randle, P. J., and Young, F. G. The mechanism of the influence of pituitary growth hormone on metabolism in Hormonal Regulation of Energy Metabolism, Laurence Kinsell, Ed. Springfield, C. C Thomas, 1957, p. 91.

17. Gordon, R. S., Jr. Unesterified fatty acid in human blood plasma. II. The transport function of unesterified fatty acid. J. clin. Invest. 1957, 36, 810.

18. Barker, S. B., and Summerson, W. H. The colori- 
metric determination of lactic acid in biological material. J. biol. Chem. 1941, 138, 535.

19. Pigafelta, P., and Macchitella, E. Adrenocorticotropic hormone (ACTH), lipide decrease and lipase activity of adrenal gland. Chir. Pat. sper. 1957, 5, 397.

20. Birmingham, M. K., Elliott, F. H., and Valère, $\mathbf{P}$. H.-L. The need for the presence of calcium for the stimulation in vitro of rat adrenal glands by adrenocorticotrophic hormone. Endocrinology 1953, 53, 687.

21. Gordon, R. S., Jr., and Cherkes, A. Production of unesterified fatty acids from isolated rat adipose tissue incubated in vitro. Proc. Soc. exp. Biol. (N. Y.) 1958, 97, 150.

22. White, J. E., and Engel, F. L. The specificity of epi- nephrine-induced lipolysis in rat adipose tissue in vitro. Clin. Res. 1958, 6, 266.

23. Raben, M. S., and Hollenberg, C. H. Effect of growth hormone on plasma fatty acids (abstract). J. clin. Invest. 1958, 37, 922.

24. Winegrad, A. I., Shaw, W. N., and Renold, A. E. Depression by growth hormone of the phosphogluconate oxidative pathway in adipose tissue (abstract). J. clin. Invest. 1958, 37, 943.

25. Krahl, M. E. Effect of pituitary hormones on me tabolism of isolated tissues in International Symposium on The Hypophyseal Growth Hormone, Nature and Actions, Richmond W. Smith, Jr., Oliver H. Gaebler, and C. N. H. Long, Eds. New York, Blakiston Division of McGraw-Hill Book Company, Inc., 1955, p. 369. 